\title{
Peluang Pengenaan Biaya Penilaian Merger dan Akuisisi sebagai Sumber Pendanaan untuk Mendukung Transformasi Ekonomi
}

Rolly Purnomo

Perencana Ahli Pratama di Direktorat Perdagangan, Investasi dan Kerjasama Ekonomi Internasional, Kementerian PPN/Bappenas

Korespondensi: rolly@bappenas.go.id

Doi: doi.org/10.47266/bwp.v4i1.90| halaman: 47-63

Dikirim: 22-02-2021 | Diterima: 29-03-2021 | Dipublikasikan: 31-03-2021

\begin{abstract}
Abstraksi
Pengendalian merger dan akusisi merupakan salah satu kegiatan di dalam Program Pengawasan Persaingan Usaha yang merupakan program pendukung terciptanya daya saing dan struktur ekonomi yang lebih baik dalam rangka mewujudkan transformasi ekonomi. Aktivitas utama pengendalian merger meliputi penilaian atas penyampaian notifikasi dan permohonan konsultasi merger dan akuisisi yang pada dua tahun terakhir menunjukkan peningkatan yang sangat signifikan. Pada situasi pandemi ini kemampuan pendanaan negara untuk membiayai penilaian merger dan akusisi menjadi sangat terbatas padahal di lain sisi terdapat peluang untuk mengurangi beban pembiayaan tersebut melalui partisipasi pelaku usaha melalui kerangka PNBP. Pengenaan biaya atas penilaian merger dan akuisisi ini sudah banyak diterapkan di berbagai negara dengan berbagai variasinya. Berdasarkan tinjauan regulasi khususnya UU No. 9/2018, pengenaan biaya tersebut juga sangat mungkin diterapkan di Indonesia karena penilaian merger dan akuisisi merupakan wujud dari pelaksanaan amanat UU No. 5/1999 yang wajib dilaksanakan oleh KPPU. Agar peluang pengenaan biaya atas penilaian merger dan akuisisi dapat diimplementasikan maka KPPU perlu merumuskan jenis PNBP atas penilaian merger dan akuisisi serta tarif atas jenis PNBP tersebut yang kemudian dilanjutkan dengan pengusulan perubahan terhadap PP No. 68/2015.
\end{abstract}

Kata kunci: merger, akuisisi, penggabungan, peleburan, pengambilalihan, persaingan usaha, KPPU, PNBP. 


\title{
Peluang Pengenaan Biaya Penilaian Merger dan Akuisisi sebagai Sumber Pendanaan untuk Mendukung Transformasi Ekonomi
}

\author{
Rolly Purnomo
}

\section{Pendahuluan}

Rencana Pembangunan Jangka Menengah Nasional Tahun 2020-2024 (RPJMN 2020-2024) telah mencanangkan bahwa perkuatan ketahanan ekonomi untuk pertumbuhan yang berkualitas dan berkeadilan menjadi salah satu agenda nasional. Agenda nasional tersebut merupakan penjabaran dari arahan Presiden terkait transformasi ekonomi dari ketergantungan sumber daya alam menjadi daya saing manufaktur dan jasa modern yang mempunyai nilai tambah tinggi bagi kemakmuran bangsa demi keadilan sosial bagi seluruh rakyat Indonesia dengan sasaran rata-rata pertumbuhan 5,7-6,0 persen per tahun dengan struktur ekonomi yang lebih baik.

Berkenaan dengan hal itu, Program Pengawasan Persaingan Usaha yang bertujuan untuk menciptakan iklim usaha yang kondusif melalui persaingan usaha yang sehat ditetapkan sebagai salah satu program pendukung terciptanya daya saing dan struktur ekonomi yang lebih baik tersebut. Dalam pelaksanaannya, program ini dijalankan oleh Komisi Persaingan Usaha (KPPU) yang diamanatkan melaksanakan Undang-Undang Nomor 5 Tahun 1999 tentang Larangan Praktek Monopoli dan Persaingan Usaha Tidak Sehat (UU No. 5/1999), serta melaksanakan beberapa ketentuan di dalam Undang-Undang Nomor 20 Tahun 2008 tentang Usaha Mikro, Kecil dan Menengah (UU No. 20/2008), Undang-Undang Nomor 11 Tahun 2020 tentang Cipta Kerja (UU No. 11/2020), dan Peraturan Pemerintah Nomor 44 Tahun 2021 tentang Pelaksanaan Larangan Praktek monopoli dan Persaingan Usaha Tidak Sehat (PP No. 44/2021).

Salah satu tugas utama KPPU sebagaimana diamanatkan oleh UU No. 5/1999 adalah melakukan penilaian terhadap perjanjian, kegiatan usaha / tindakan pelaku usaha, dan posisi dominan yang dapat mengakibatkan praktek monopoli dan persaingan usaha tidak sehat. Praktek monopoli didefinisikan sebagai upaya pemusatan kekuatan ekonomi sehingga membuat suatu pelaku usaha dapat menjadi penentu harga barang/jasa (price maker), sedangkan persaingan usaha tidak sehat diartikan sebagai cara berkompetisi yang dilakukan dengan tidak jujur, melawan hukum atau menghambat persaingan. Merger dan akuisi merupakan salah satu praktek yang menurut UU No. 5/1999 perlu diawasi dalam konteks penciptaan posisi dominan dalam suatu pasar bersangkutan yang sama (antar pelaku usaha pesaing) atau dalam pasar bersangkutan berbeda baik yang terkait (penciptaan integrasi vertikal) maupun tidak terkait (upaya konglomerasi).

Pada dasarnya transaksi merger dan akuisisi bertujuan untuk meningkatkan efisiensi melalui peningkatan skala dan cakupan ekonomi. Namun demikian, di lain sisi, merger dan akuisisi juga dapat memperbesar tingkat konsentrasi pasar yang pada akhirnya meningkatkan kekuatan pasar (market power) salah satu pelaku usaha. Kekuatan pasar inilah yang kemudian dikhawatirkan dapat disalahgunakan untuk menguasai pasar secara tidak jujur, melawan hukum atau menghambat persaingan. 
Untuk itu, setiap pelaku usaha yang berusaha di Indonesia dan melakukan merger maupun akuisisi diwajibkan memberitahukan (menyampaikan notifikasi) transaksinya tersebut kepada KPPU paling lambat 30 hari setelah transaksi efektif untuk dilakukan penilaian dampaknya terhadap persaingan usaha. Keterlambatan dalam menyampaikan notifikasi tertulis dapat dikenakan sanksi denda administratif sebesar Rp 1 miliar per hari keterlambatan.

Ketentuan ini menunjukkan bahwa Indonesia menganut pendekatan post-notifikasi atau kewajiban penyampaian notifikasi dilakukan setelah terjadi merger dan akuisisi. Selain pendekatan post-notifikasi, banyak juga negara-negara yang menganut pendekatan prenotifikasi atau penyampaian notifikasi wajib dilakukan sebelum transaksi efektif untuk mendapatkan persetujuan merger dan akuisisi. Lebih lanjut, ada juga negara yang tidak mewajibkan penyampaian notifikasi atau menganut pendekatan notifikasi sukarela (voluntary notification) namun otoritas persaingan usahanya tetap dapat melakukan investigasi atas merger dan akuisisi yang dilakukannya.

Pendekatan post-notifikasi dan notifikasi sukarela dinilai akan menyebabkan ketidakpastian bagi pelaku usaha karena otoritas persaingan dapat saja membatalkan hasil merger dan akuisisi yang telah terjadi jika hasil penilaiannya menunjukkan potensi terjadinya praktek monopoli dan/atau persaingan usaha tidak sehat. Sedangkan pendekatan pre-notifikasi dianggap lebih memberikan kepastian hukum bagi pelaku usaha dalam melakukan merger dan akuisisi serta otoritas persaingan usaha dapat mencegah dampak negatif terhadap persaingan usaha sejak awal. Oleh karena itu, dalam beberapa kesempatan untuk merevisi UU No. 5/1999, KPPU berupaya mengajukan perubahan ketentuan penyampaian transaksi merger dan akuisisi menjadi pre-notifikasi. Namun demikian, pendekatan pre-notifikasi bukanlah tidak beresiko karena jika tidak didukung oleh sumber daya manusia dan pendanaan yang memadai maka akan dapat menyebabkan terjadi keterlambatan penilaian yang berpotensi menghambat kegiatan perekonomian (Ragazzo, CEJ., dan Albuquerque, CL. 2012).

Jumlah notifikasi merger dan akuisi yang diterima KPPU berdasarkan data selama satu dekade sebagaimana disajikan pada Gambar 1 menunjukkan peningkatan. Dalam dua tahun terakhir terlihat terdapat lonjakan yang cukup signifikan. Konsekuensi peningkatan jumlah penyampaian notifikasi tersebut tentunya membutuhkan tambahan sumber daya untuk menjalankan tugas penilaian merger dan akuisisi tersebut. Konsekuensinya tentunya berimplikasi pada peningkatan kebutuhan anggaran yang harus didanai oleh negara melalui Anggaran Pendapatan dan Belanja Negara (APBN). 


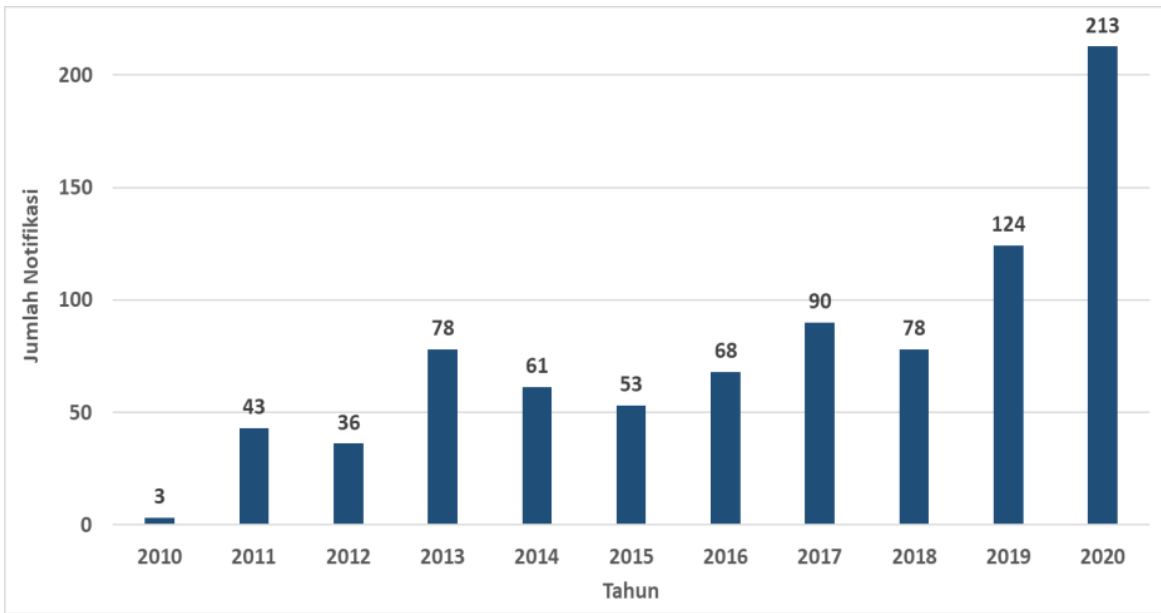

Gambar 1. Jumlah Notifikasi Merger dan Akuisisi Tahun 2010 - 2020 Sumber: Laporan Tahunan KPPU 2018, Laporan Tahunan KPPU 2019, dan https://kppu.go.id/blog/2020/12/catatan-kinerja-kppu-di-tahun-2020/ (diolah)

Kecenderungan transaksi merger dan akuisisi nampaknya akan terus meningkat dan berimplikasi pada kebutuhan pendanaan yang juga meningkat. Pada situasi pandemi saat ini dimana keuangan negara sedang diarahkan untuk kegiatan lainnya yang lebih prioritas, peningkatan kebutuhan anggaran tersebut kemungkinan besar akan sulit dipenuhi. Oleh karena itu, agar proses penilaian merger dan akusisi dapat berjalan sesuai ketentuan maka perlu dicarikan terobosan terkait pendanaan tersebut. Salah satu ide yang berkembang adalah dengan mengenakan biaya atas pelayanan KPPU dalam melakukan penilaian merger dan akusisi melalui kerangka penerimaan negara bukan pajak (PNBP).

Tulisan ini ditujukan untuk melihat peluang pengenaan biaya atas penilaian merger dan akusisi tersebut dengan bercermin dari praktek yang berlangsung di beberapa negara (benchmarking) dan berdasarkan ketentuan yang ada.

\section{Metodologi}

Analisis untuk memenuhi tujuan penulisan ini dilakukan secara kualitatif berdasarkan informasi mengenai prosedur penanganan notifikasi merger dan akuisisi di KPPU, praktek pengenaan tarif notifikasi (notification filing fee) merger dan akuisisi di beberapa negara dan pendalaman mengenai prinsip-prinsip pengenaan biaya yang tertuang di dalam peraturan perundang-udangan mengenai PNBP.

Alur penulisan mengikuti urutan pembahasan tersebut di atas dan dilanjutkan dengan penarikan kesimpulan mengenai peluang pengenaan biaya atas penilaian merger dan akuisisi dan ditutup dengan perumusan rekomendasi tindaklanjut.

\section{Penilaian Merger dan Akuisisi di Indonesia}

Ketentuan persaingan usaha atas transaksi merger dan akusisi di Indonesia diatur di dalam Pasal 28 dan Pasal 29 UU No. 5/1999 serta aturan turunannnya yaitu Peraturan Pemerintah Nomor 57 tahun 2010 tentang Penggabungan Atau Peleburan Badan Usaha 
Dan Pengambilalihan Saham Perusahaan Yang Dapat Mengakibatkan Terjadinya Praktik Monopoli Dan Persaingan Usaha Tidak Sehat (PP No. 57/2010) dan Peraturan KPPU Nomor 3 tahun 2019 tentang Penilaian Terhadap Penggabungan atau Peleburan Badan Usaha, atau Pengambilalihan Saham Perusahaan Yang Dapat Mengakibatkan Terjadinya Praktik Monopoli dan/atau Persaingan Usaha Tidak Sehat (Perkom No. 13/2019).

Merger dan akuisisi di dalam ketentuan tersebut dikenal dengan istilah penggabungan, peleburan dan pengambilalihan. Secara sederhana penggabungan dapat diartikan sebagai merger yang menyebabkan hanya satu badan usaha yang tetap sedangkan badan usaha lain yang menggabungkan diri menjadi terlikuidasi atau berakhir demi hukum. Sedangkan peleburan adalah merger yang mengakibatkan seluruh badan usaha yang terlibat terlikuidasi atau berakhir demi hukum dan terbentuknya suatu badan hukum baru sebagai penggantinya. Selanjutnya, istilah pengambilalihan adalah sebutan lain untuk akuisisi. Jika pada UU No. 5/1999 dan PP No. 57/2010 hanya dikenal istilah pengambilalihan saham namun pada Perkom No. 13/2019 definisi pengambilalihan diperluas dengan menambahkan pengambilalihan aset. Seluruh ketentuan pengambilalihan aset ini dipersamakan dengan ketentuan dalam pengambilalihan saham. Untuk selanjutnya, dalam tulisan ini digunakan istilah yang lebih umum yaitu merger yang berarti penggabungan atau peleburan dan akuisisi yang bermakna pengambilalihan saham atau aset.

Peraturan perundang-undangan menyatakan merger dan akuisisi dilarang jika menyebabkan praktek monopoli dan/atau persaingan usaha tidak sehat. Frasa 'jika menyebabkan praktek monopoli dan/atau persaingan usaha tidak sehat' menunjukkan ketentuan ini bersifat rule of reason atau tidak serta merta dilarang namun perlu dilakukan penilaian terlebih dahulu apakah kegiatan tersebut diperkirakan berpotensi memberikan dampak negatif terhadap persaingan. Jika hasil penilaian menyimpulkan tidak terdapat potensi tersebut maka transaksi merger dan akuisisi diperbolehkan.

Secara umum proses penilaian merger dan akusisi berlangsung dalam 2 tahap yang meliputi tahap klarifikasi dan penelitian dokumen yang berlangsung paling lama 60 hari kerja dan jika diperlukan dapat dilanjutkan ke tahap penilaian dengan waktu pelaksanaan paling lama 90 hari kerja. Tahap penilaian sendiri sesuai kebutuhannya dapat terdiri dari 2 tahap yaitu penilaian awal dan penilaian menyeluruh. Selain itu, dimungkinkan pula untuk menyampaikan notifikasi dengan permohonan penilaian sederhana dengan jangka waktu pelaksanaan paling lama 14 hari kerja.

\subsection{Klarifikasi dan Penelitian Atas Notifikasi}

Kewajiban notifikasi ini hanya berlaku untuk merger dan akuisisi antar pelaku usaha yang menyebabkan nilai aset gabungannya melebihi Rp. 2,5 triliun dan/atau nilai penjualan gabungannya melebihi Rp. 5 triliun. Khusus antar pelaku usaha perbankan batasannya adalah jika nilai aset gabungannya melebihi Rp. 20 triliun. Sedangkan untuk merger dan akuisisi yang nilai aset dan/atau nilai penjualan gabungannya dibawah nilai tersebut tidak diwajibkan untuk melakukan notifikasi. Selain itu, merger dan akuisisi antar pelaku usaha yang terafiliasi juga dikecualikan dari kewajiban notifikasi tersebut.

Setelah pelaku usaha menyampaikan notifikasi tertulis dan dinyatakan lengkap, KPPU akan melakukan klarifikasi dan penelitian atas informasi dan dokumen pendukung. Salah satu tujuan proses klarifikasi dan penelitian dokumen ini adalah untuk memastikan 
apakah merger dan akuisisi tersebut termasuk dalam kriteria yang harus ditindaklanjuti baik dari sisi nilai aset dan/atau penjualan gabungan atau dari aspek lain seperti apakah merupakan badan terafiliasi.

Jika dari proses klarifikasi dan penelitian disimpulkan bahwa merger dan akuisisi tersebut tidak termasuk kriteria dimaksud maka KPPU akan mengeluarkan Penetapan Tidak Wajib Notifikasi atas transaksi yang diberitahukan. Namun bila kesimpulannya transaksi merger dan akuisisi adalah memenuhi kriteria tersebut maka prosesnya dilanjutkan ke tahap penilaian.

\subsection{Penilaian Awal}

Penilaian awal ditujukan untuk menganalisis apakah merger dan akuisisi tersebut akan berdampak terhadap persaingan usaha di industri dan/atau pasar. Terdapat 3 kondisi pasar berbeda terkait merger dan akuisisi tersebut dengan penekanan analisis yang juga berbeda.

Pertama, jika merger dan akuisisi terjadi antara pelaku usaha yang bersaing atau dalam satu pasar bersangkutan (relevant market) maka penilaian awal dititikberatkan pada analisis konsentrasi pasar dan perubahannya. Dalam hal ini KPPU menggunakan perhitungan konsentrasi pasar berdasarkan metode Herfindahl-Hirschman Index $\left(\mathrm{HHI}=\sum\right.$ (Pangsa Pasar $)^{2}$ ) dan/atau Concentration Ratio. Dalam hal yang digunakan adalah metode HHI maka tingkat konsentrasi pasar dibagi dalam 3 spektrum, yaitu: (i) Spektrum 1 dengan HHI lebih kecil dari 1.500 (HHI<1.500), (ii) Spektrum 2 dengan HHI lebih besar atau sama dengan 1.500 namun lebih kecil atau sama dengan $2.500(1.500 \leq \mathrm{HHI} \leq 2.500)$, dan (iii) Spektrum 3 dengan HHI lebih besar dari 2.500 (HHI>2.500).

Penilaian awal tidak perlu dilanjutkan ke tahap penilaian menyeluruh apabila salah satu kondisi sebagai berikut terpenuhi:

- konsentrasi pasar berada pada Spektrum 1 (HHI $<1.500)$,

- konsentrasi pasar berada pada Spektrum 2 dan perubahan HHI setelah dan sebelum merger dan akuisisi lebih kecil atau sama dengan $250(1.500 \leq \mathrm{HHI} \leq 2.500$ dan $\Delta \mathrm{HHI} \leq 250)$, atau

- konsentrasi pasar berada pada Spektrum 3 dan perubahan HHI setelah dan sebelum merger dan akuisisi lebih kecil atau sama dengan 150 ( $\mathrm{HHI}>2.500$ dan $\Delta \mathrm{HHI} \leq 150)$.

Namun, jika kondisi tersebut tidak terpenuhi maka penilaian akan dilanjutkan ke tahap penilaian menyeluruh.

Kedua, dalam hal merger dan akuisisi terjadi antar pelaku usaha dengan pasar bersangkutan yang berbeda namun bersifat komplemen atau terkait secara vertikal maka penilaian awal akan diarahkan pada ada atau tidak adanya kekuatan pasar atau dominasi di pasar hulu dan/atau hilir. Jika tidak terdapat kekuatan pasar atau dominasi baik di pasar hulu maupun pasar hilir maka penilaian tidak akan dilanjutkan ke tahap penilaian menyeluruh dan demikian pula sebaliknya.

Ketiga, jika transaksi merger dan akuisisi terjadi antar pelaku usaha yang bukan pesaing dan bukan merupakan komplemen (bersifat konglomerasi) maka analisis pada penilaian awal akan ditekankan untuk menilai keberadaan potensi tying dan/atau bundling. 
Jika tidak terdapat potensi tying dan/atau bundling maka maka penilaian juga tidak akan dilanjutkan ke tahap penilaian menyeluruh dan demikian pula sebaliknya.

Jika penilaian awal tidak dilanjutkan ke penilaian menyeluruh maka akan diterbitkan Penetapan Notifikasi yang menyatakan pendapat KPPU bahwa tidak adanya dugaan praktik monopoli atau persaingan usaha tidak sehat.

\subsection{Penilaian Menyeluruh}

Penilaian menyeluruh merupakan kelanjutan dari penilaian awal setelah disimpulkan terdapat kekuatiran adanya praktik monopoli dan/atau persaingan usaha tidak sehat karena perubahan struktur pasar yang terjadi cukup signifikan, terdapat kekuatan pasar atau dominasi di pasar hulu dan/atau hilir, atau terdapat potensi tying dan/atau bundling. Dalam tahapan ini, hasil analisis yang dilakukan pada tahap sebelumnya dilanjutkan dengan bebarapa analisis lain yang meliputi analisis hambatan masuk pasar, analisis potensi perilaku anti persaingan, analisis efisiensi dan/atau analisis kepailitan. Selain itu dapat juga dilakukan analisis lain yang relevan seperti analisis yang mempertimbangkan: (i) kebijakan peningkatan daya saing dan penguatan industri nasional, (ii) pengembangan teknologi dan inovasi, (iii) perlindungan usaha mikro, kecil, dan menengah, (iv) dampak terhadap tenaga kerja, serta (v) pelaksanaan peraturan perundang-undangan.

Setelah dilakukan penilaian menyeluruh, KPPU menerbitkan Penetapan Notifikasi yang memuat pendapat KPPU berkenaan dengan merger dan akuisisi yang dinotifikasi. Terdapat 3 kemungkinan pendapat KPPU tersebut yaitu: (i) tidak adanya dugaan praktik monopoli atau persaingan usaha tidak sehat, (ii) adanya dugaan praktik monopoli atau persaingan usaha tidak sehat, atau (iii) adanya dugaan praktik monopoli atau persaingan usaha tidak sehat dengan persetujuan bersyarat.

\subsection{Penilaian Sederhana}

Pelalu usaha yang melakukan transaksi merger dan akuisisi dapat menyampaikan notifikasi dengan permohonan penilaian sederhana. Secara umum, kriteria penilaian sederhana adalah apabila pelaku usaha meyakini bahwa berdasarkan analisis pasar bersangkutan dan konsentrasi pasar, tidak terdapat isu persaingan atau tidak terdapat potensi penurunan persaingan secara signifikan. Selain itu, penilaian sederhana dapat pula dilakukan berdasarkan pertimbangan KPPU.

Terdapat 2 kemungkin keluaran dari hasil penilaian sederhana, yaitu: (i) Penetapan Notifikasi yang menyatakan tidak adanya dugaan praktik monopoli atau persaingan usaha tidak sehat, dan (ii) Surat Pemberitahuan dilaksanakannya prosedur Notifikasi regular jika ternyata kriteria penilaian sederhana tidak terpenuhi.

\subsection{Konsultasi Sebelum Merger Dan Akuisisi}

Pelaku usaha dapat pula melakukan konsultasi secara lisan atau tertulis kepada KPPU sebelum melakukan proses merger dan akuisisi. Konsultasi ini bersifat sukarela dan bertujuan meminimalkan risiko yang mungkin dialami oleh pelaku usaha dalam merencanakan transaksi tersebut. KPPU melakukan penilaian berdasarkan formulir dan dokumen yang diterima dalam proses konsultasi dan akan memberikan saran, bimbingan, dan/atau pendapat tertulis kepada pelaku usaha dalam jangka waktu paling lama 90 hari kerja setelah sebelumnya dilakukan proses klarifikasi dan penelitian dokumen. 
Analisis dan prosedur yang digunakan dalam penilaian konsultasi mirip dengan analisis dan prosedur pada proses notifikasi. Hasil dari konsultasi tersebut adalah berupa Penetapan Konsultasi yang memuat pendapat KPPU atas hasil konsultasi tertulis dengan 3 kemungkinan pendapat yang sama dengan pada proses penilaian notifikasi. Penetapan Konsultasi ini tidak menghapuskan kewajiban pelaku usaha untuk menyampaikan notifikasi setelah merger dan akuisisi efektif. Namun demikian, Penetapan Konsultasi ini dapat digunakan untuk mendukung proses notifikasi untuk transaksi merger dan akuisisi yang terjadi paling lama 2 tahun setelah Penetapan Konsultasi tersebut ditanda tangani. Sebagai catatan, KPPU tetap berwenang untuk melakukan penilaian ulang terutama jika terdapat perubahan data yang cukup esensial.

\section{Praktek Pengenaan Biaya Penilaian Merger dan Akuisisi di Beberapa Negara}

Semua negara umumnya melarang praktek merger dan akuisisi (beberapa negara menggunakan istilah combination atau concentration sebagai pengganti istilah merger dan akuisisi) yang dapat menyebabkan pelemahan persaingan usaha yang cukup signifikan. Oleh karena itu, negara-negara yang mempunyai peraturan mengenai persaingan usaha umumnya mempunyai prosedur pengendalian merger dan akuisisi atau dikenal dengan istilah merger control yang pada intinya berisi langkah-langkah untuk menilai potensi dampak yang diakibatkan oleh suatu merger dan akuisisi.

Umumnya pendekatan merger control adalah bersifat ex-ante (pencegahan atas potensi perilaku antipersaingan yang belum terjadi dan masih bersifat potensi dampak) dan rule of reason, namun tiap negara mempunyai pendekatan yang berbeda-beda dalam hal kewajiban notifikasi dan tahapan penilaiannya. Ada negara yang mewajibkan notifikasi dengan pendekatan pre-notifikasi (seperti India, Jerman, Belanda, Amerika Serikat dan Kanada), post-notifikasi (seperti Indonesia dan Filipina) atau kombinasi keduanya (seperti Thailand). Selain itu ada juga negara-negara yang tidak mewajibkan notifikasi atau notifikasinya bersifat sukarela (seperti Singapura, Australia dan Inggris).

Negara-negara yang mewajibkan notifikasi umumnya mengatur batasan (threshold) nilai aset gabungan dan/atau nilai penjualan (omset) gabungan bagi transaksi merger dan akuisisi yang wajib melakukan notifikasi. Transaksi yang nilai aset dan/atau penjualan (omset) gabungan tidak memenuhi batasan tersebut tidak diwajibkan menyampaikan notifikasi dan dianggap tidak membahayakan persaingan usaha. Namun demikian, umumnya otoritas persaingan tetap dapat melakukan investigasi atas transaksi tersebut. Khusus untuk Thailand, threshold tersebut digunakan untuk menentukan pendekatan notifikasi yang akan dipakai. Jika di bawah threshold maka yang berlaku adalah pendekatan post-notifikasi sedangkan bila di atas threshold maka digunakan pendekatan pre-notifikasi (Mergerfilers.com 2021).

Selanjutnya, terkait tahapan dalam melakukan penilaian merger dan akuisisi, kebanyakan negara membaginya dalam beberapa tahap dengan maksimum waktu yang telah ditentukan atau berdasarkan kesepakatan dengan pelaku usaha. Tujuannya adalah untuk memberi kepastian dan memilah-milah antara transaksi merger dan akuisisi yang bersifat sederhana dengan yang bersifat kompleks. Transaksi yang bersifat sederhana biasanya hanya membutuhkan analisis sederhana dan penilaian dapat diselesaikan pada tahap awal 
atau tahap inisial. Namun demikian, ada juga negara seperti Australia yang hanya menerapkan satu tahap penilaian bagi pelaku usaha yang mengajukan persetujuan sebelum merger / pre-merger authorisation (ACCC 2021).

Selain itu, sebagian besar negara kecuali Amerika Serikat (FTC 2021) memberikan kesempatan kepada pelaku usaha untuk berkonsultasi baik formal maupun informal mengenai rencana transaksi merger dan akusisinya. Umumnya pada saat konsultasi ini pelaku usaha dilarang menyelesaikan transaksinya dan pendapat dari hasil konsultasi tidak bersifat mengikat namun dapat digunakan dalam proses notifikasi nantinya. Oleh karena itu, walaupun telah dilakukan konsultasi, jika dibutuhkan, otoritas persaingan tetap mempunyai kewenangan untuk melakukan investigasi atau penilaian ulang khususnya dalam hal asumsi yang digunakan dalam konsultasi ternyata berbeda dengan pada saat notifikasi. Tabel 1 menyajikan ringkasan perbandingan ketentuan notifikasi dan penilaian merger dan akuisisi di beberapa negara.

Tabel 1. Ketentuan Notifikasi dan Penilaian Merger dan Akusisi di Beberapa Negara

\begin{tabular}{|c|c|c|c|c|c|}
\hline No & Negara & $\begin{array}{l}\text { Kewajiban } \\
\text { Notifikasi }\end{array}$ & $\begin{array}{l}\text { Threshold } \\
\text { Wajib } \\
\text { Notifikasi }\end{array}$ & Tahapan Penilaian & $\begin{array}{l}\text { Konsultasi } \\
\text { Pra- } \\
\text { notifikasi }\end{array}$ \\
\hline 1 & Singapura & $\begin{array}{c}\text { Sukarela } \\
\text { (voluntary) }\end{array}$ & Tidak ada & $\begin{array}{l}\text { Tahap } 1 \text { (30 hari) } \\
\text { Tahap } 2 \text { (120 hari) }\end{array}$ & Ada \\
\hline 2 & Filipina & $\begin{array}{c}\text { Wajib } \\
\text { (post-notifikasi) }\end{array}$ & $\begin{array}{c}\text { Ada } \\
\text { (aset \& omset) }\end{array}$ & $\begin{array}{l}\text { Inisial (15 hari) } \\
\text { Tahap } 1 \text { (30 hari) } \\
\text { Tahap } 2 \text { (60 hari) }\end{array}$ & Ada \\
\hline 3 & Thailand & $\begin{array}{c}\text { Wajib } \\
\text { (pre dan post } \\
\text { notifikasi) }\end{array}$ & Ada & $\begin{array}{l}\text { Satu tahap untuk persetujuan pra- } \\
\text { merger ( } 90 \text { hari + perpanjangan } 15 \\
\text { hari) }\end{array}$ & Ada \\
\hline 4 & India & $\begin{array}{c}\text { Wajib } \\
\text { (pre-notifikasi) }\end{array}$ & $\begin{array}{c}\text { Ada } \\
\text { (aset \& omset) }\end{array}$ & $\begin{array}{l}\text { Form } 1 \text { - sederhana } \\
\text { Form } 2 \text { - menyeluruh }\end{array}$ & Ada \\
\hline 5 & Australia & $\begin{array}{c}\text { Sukarela } \\
\text { (voluntary) }\end{array}$ & Tidak ada & $\begin{array}{l}\text { Satu tahap untuk otorisasi Pra } \\
\text { merger (90 hari) }\end{array}$ & Ada \\
\hline 6 & Inggris & $\begin{array}{c}\text { Sukarela } \\
\text { (voluntary) }\end{array}$ & Tidak ada & $\begin{array}{l}\text { Tahap } 1 \\
\text { Tahap } 2 \text { (24 minggu }+8 \text { minggu } \\
\text { perpanjangan) }\end{array}$ & Ada \\
\hline 7 & Jerman & $\begin{array}{c}\text { Wajib } \\
\text { (pre-notifikasi) }\end{array}$ & $\begin{array}{c}\text { Ada } \\
\text { (omset) }\end{array}$ & $\begin{array}{l}\text { Tahap } 1 \text { ( } 1 \text { bulan }) \\
\text { Tahap } 2 \text { ( } 4 \text { bulan })\end{array}$ & Ada \\
\hline 8 & Belanda & $\begin{array}{c}\text { Wajib } \\
\text { (pre-notifikasi) }\end{array}$ & $\begin{array}{c}\text { Ada } \\
\text { (omset) }\end{array}$ & $\begin{array}{l}\text { Tahap } 1 \text { (4 minggu }) \\
\text { Tahap } 2 \text { (13 minggu) }\end{array}$ & Ada \\
\hline 9 & $\begin{array}{l}\text { Amerika } \\
\text { Serikat }\end{array}$ & $\begin{array}{c}\text { Wajib } \\
\text { (pre-notifikasi) }\end{array}$ & Ada & $\begin{array}{l}\text { Waktu tunggu pertama (30 hari) } \\
\text { Waktu tunggu kedua (kesepakatan) }\end{array}$ & Tidak Ada \\
\hline 10 & Kanada & $\begin{array}{c}\text { Wajib } \\
\text { (pre-notifikasi) }\end{array}$ & Ada & $\begin{array}{l}\text { Waktu tunggu pertama (30 hari) } \\
\text { Waktu tunggu kedua (30 hari) }\end{array}$ & Ada \\
\hline
\end{tabular}

Sumber: dari beberapa sumber (diolah)

Selain ketentuan notifikasi dan tahapan penilaian, negara-negara juga mempunyai pendekatan yang cukup beragam mengenai perlu tidaknya partisipasi pelaku usaha yang 
melakukan atau akan melakukan merger dan akuisisi dalam hal pendanaan kegiatan penilaian transaksi tersebut. Ada negara-negara yang tidak membebankan biaya atas penyampaian (filing) notifikasi dan kegiatan penilaian tersebut seperti Jepang, Korea Selatan, dan China. Namun tidak sedikit pula negara-negara yang membebankan biaya penilaian dampak merger/akuisisi kepada pelaku usaha yang menyampaikan notifikasi.

Model pengenaan biaya notifikasi beberapa negara cukup bervariasi. Singapore misalnya, besaran biaya notifikasi yang dikenakan tergantung dari kategori pelaku usaha dan nilai penjualan gabungan (CCCS 2021). Untuk transaksi merger dan akuisisi antar usaha kecil dan menengah biaya notifikasinya relatif kecil. Untuk usaha besar, semakin besar nilai penjualan gabungan maka akan semakin besar biaya notifikasinya.

Selain itu ada juga negara-negara yang menetapkan biaya notifikasi berdasarkan tahapan dalam penilaian notifikasi. Implikasinya, untuk transaksi merger dan akuisisi sederhana yang hanya membutuhkan penilaian di tahap awal maka biaya notifikasinya akan lebih rendah dibanding yang membutuhkan penilaian di tahap berikutnya. Lebih lanjut ada juga negara yang hanya menetapkan satu jenis biaya notifikasi untuk keseluruhan proses penilaian tanpa membedakan sederhana atau kompleksnya analisis yang dibutuhkan. Kemudian ada juga negara yang hanya menentukan batas atas biaya notifikasi dan biaya yang dibebankan akan tergantung dari tingkat kesulitan dalam penilaian. Tabel 2 memberikan gambaran ringkas tentang penerapan biaya notifikasi merger dan akuisisi di beberapa negara.

Tabel 2. Biaya Notifkasi Merger dan Akuisisi Di Beberapa Negara

\begin{tabular}{|c|c|c|c|}
\hline No & Negara & Biaya Penilaian Merger/Akuisisi & Keterangan \\
\hline 1 & Singapura & $\begin{array}{l}\text { Berkisar antara SGD } 5.000 \text { dan SGD } 100.000 \\
( \pm \text { a Rp. } 52,5 \text { juta } \mathrm{s} / \mathrm{d} \pm \text { Rp. } 1,05 \text { miliar })\end{array}$ & $\begin{array}{l}\text { Tergantung kategori } \\
\text { pelaku usahanya dan nilai } \\
\text { penjualan gabungan }\end{array}$ \\
\hline 2 & Filipina & $\begin{array}{l}\text { Berkisar antara PHP } 150.000,- \text { dan PHP } 5 \text { juta } \\
( \pm \text { Rp. } 43,6 \text { juta } \mathrm{s} / \mathrm{d} \pm \text { Rp. } 1,46 \text { miliar })\end{array}$ & $\begin{array}{l}\text { Tergantung dari kategori } \\
\text { tahapan dan jenis review }\end{array}$ \\
\hline 3 & Thailand & THB $250.000,-( \pm$ Rp. 117 juta $)$ & Untuk pre-merger approval \\
\hline 4 & India & $\begin{array}{l}\text { Lakh } 15=\text { INR 1.500.000 ( } \pm \text { Rp } 289 \text { juta }) \\
\text { Lakh } 50=\text { INR 5.000.000 }( \pm \text { Rp } 963 \text { juta })\end{array}$ & $\begin{array}{l}\text { Menggunakan Form I } \\
\text { Menggunakan Form II }\end{array}$ \\
\hline 5 & Australia & AUD $25.000,-( \pm$ Rp. 269 juta $)$ & $\begin{array}{l}\text { Jika ingin mendapatkan } \\
\text { merger authorisation atau } \\
\text { revocation and substitution }\end{array}$ \\
\hline 6 & Inggris & $\begin{array}{l}\text { Berkisar antara GBP } 40.000 \text { dan GBP } 160.000 \\
( \pm \text { a Rp. } 771 \text { juta } \mathrm{s} / \mathrm{d} \pm \text { Rp. } 3,1 \text { miliar })\end{array}$ & $\begin{array}{l}\text { Untuk penilaian tahap } 2 \\
\text { dan tergantung omset } \\
\text { pelaku usahanya }\end{array}$ \\
\hline 7 & Jerman & $\begin{array}{l}\text { Sampai dengan EUR 50.000,- ( } \pm \text { Rp. } 850 \text { juta }) \\
\text { Sampai dengan EUR 100.000,- }( \pm \text { Rp. } 1,7 \\
\text { milar) pada kasus tertentu }\end{array}$ & $\begin{array}{l}\text { Besarannya tergantung } \\
\text { biaya yang dikeluarkan } \\
\text { untuk penilaian }\end{array}$ \\
\hline 8 & Belanda & $\begin{array}{l}\text { EUR 17.450,- }( \pm \text { Rp. } 295 \text { juta }) \\
\text { EUR } 34.900,-( \pm \text { Rp. } 590 \text { juta })\end{array}$ & $\begin{array}{l}\text { Penilaian tahap } 1 \\
\text { Penilaian tahap } 2\end{array}$ \\
\hline 9 & Amerika Serikat & $\begin{array}{l}\text { Berkisar antara USD } 45.000 \text { dan USD } 280.000 \\
( \pm \text { Rp. } 639 \text { juta } \mathrm{s} / \mathrm{d} \pm \text { Rp. } 3,9 \text { miliar })\end{array}$ & Tergantung nilai transaksi \\
\hline
\end{tabular}




\begin{tabular}{|c|l|l|l|}
\hline No & Negara & Biaya Penilaian Merger/Akuisisi & Keterangan \\
\hline 10 & Kanada & CAD $75.055,68( \pm$ Rp. 827 juta $)$ & $\begin{array}{l}\text { Biaya per 1 April 2021 dan } \\
\text { setiap tahun disesuaikan } \\
\text { berdasarkan consumer price } \\
\text { index }(\mathrm{CPI})\end{array}$ \\
\hline
\end{tabular}

Sumber: dari beberapa sumber (diolah)

\section{Peluang Pengenaan Biaya atas Merger dan Akuisisi}

Pada prinsipnya seluruh pungutan yang menjadi pendapatan atau penerimaan pemerintah pusat yang bukan berasal dari pajak termasuk dalam kategori PNBP. Ketentuan umum mengenai PNBP diatur oleh Undang-Undang Nomor 9 tahun 2018 tentang Penerimaan Negara Bukan Pajak (UU No. 9/2018) yang menggantikan Undang-Undang Nomor 20 tahun 1997 tentang Penerimaan Negara Bukan Pajak (UU No. 20/1997). Di dalam ketentuan tersebut disebutkan bahwa sumber atau objek dari PNBP adalah seluruh aktivitas, hal, dan/atau benda yang berkaitan dengan pelaksanaan tugas dan fungsi pemerintah antara lain meliputi pemanfaatan sumber daya alam, pelayanan, pengelolaan kekayaan negara dipisahkan, pengelolaan barang milik negara, dan pengelolaan dana.

Selanjutnya UU No. 9/2018 juga menyebutkan bahwa tujuan pengaturan PNBP adalah untuk (i) meningkat kemandirian bangsa dan optimalisasi sumber pendapatan negera, (ii) mendukung kebijakan pemerintahan, serta (iii) mewujudkan pelayanan yang bersih, profesional, transparan, dan akuntabel. Keseluruhan tujuan tersebut adalah ditujukan untuk mendukung pembangunan nasional yang berkelanjutan dan berkeadilan khususnya yang berkaitan dengan pertumbuhan ekonomi yang berkualitas, perbaikan distribusi pendapatan, pelestarian lingkungan hidup serta peningkatan tata kelola pemerintahan dan pelayanan kepada masyarakat.

Dalam pelaksanaannya, objek PNBP tersebut dirinci menurut jenis dan tarifnya serta ditetapkan dalam produk hukum berupa undang-undang, peraturan pemerintah atau peraturan menteri yang menyelenggarakan urusan pemerintahan di bidang keuangan negara. Sebagai contoh untuk KPPU saat ini, ketentuan pengenaan biaya PNBP-nya tertuang di dalam Peraturan Pemerintah Nomor 68 tahun 2015 tentang Jenis dan Tarif atas Jenis PNBP yang berlaku pada KPPU (PP No. 68/2015) yang menentukan jenis dan tarif PNBP yang dapat diterapkan meliputi penerimaan atas:

a. Denda administratif yang besarannya berdasarkan putusan KPPU atau putusan pengadilan.

b. Jasa penggandaan dokumen terkait persaingan usaha dan/atau etika bisnis dalam kemitraan dengan tarif Rp. 300 per lembar untuk mahasiswa dan Rp. 800, - per lembar untuk umum).

c. Penerbitan surat keterangan bebas tanggungan berperkara dengan tarif Rp. 100.000, - per surat.

d. Pendaftaran surat kuasa untuk mewakili pihak yang berperkara dengan tarif Rp. 50.000, - per akta. 
e. Jasa pembuatan surat kuasa insidentil dengan tarif Rp. 100.000, - per surat kuasa.

f. Jasa penelusuran dokumen terkait persaingan usaha dan/atau etika bisnis dalam kemitraan yang tidak tersimpan di arsip kantor pusat KPPU dengan tarif Rp. 30.000, - per dokumen.

Saat ini kegiatan penilaian merger dan akuisisi belum terakomodasi sebagai salah satu sumber penerimaan negara seperti terlihat pada rincian di atas. Padahal jika dilihat dari aktivitasnya, kegiatan penilaian merger dan akuisisi tersebut dapat dikategorikan sebagai salah satu bentuk pelayanan bagi masyarakat yang berkaitan dengan pelaksanaan tugas dan fungsi pemerintah.

Lebih lanjut, UU No. 9/2018 menjelaskan bahwa yang dimaksud pelayanan antara lain meliputi jasa atau pelayanan administratif yang menjadi tanggung jawab pemerintah sebagai pemenuhan kebutuhan masyarakat maupun pelaksanaan ketentuan peraturan perundang-undangan. Penilaian merger dan akuisisi merupakan wujud dari pelaksanaan Pasal 28 dan Pasal 29 dari UU No. 5/1999 dan seluruh aturan turunannya yang wajib dilaksanakan oleh KPPU sebagaimana dijelaskan sebelumnya.

Oleh karena itu, sebagai upaya memperkuat kemampuan pembiayaan oleh negara dan sebagai salah satu bentuk partisipasi pelaku usaha atas layanan yang diterimanya maka pengenaan biaya atas penilaian merger dan akuisisi pada hakikatnya mempunyai landasan hukum yang memadai. Selain itu, pengenaan tarif PNBP atas kegiatan tersebut juga sejalan dengan tujuan pengenaan PNBP antara lain untuk mendukung kebijakan pemerintah serta mewujudkan pelayanan yang bersih, profesional, transparan, dan akuntabel.

Selanjutnya, untuk menentukan jenis pelayanan yang dikenakan biaya PNBP perlu dilakukan pendalaman dengan berbagai pertimbangan yang salah satunya adalah dengan melihat proses penilaian merger dan akuisisi serta dengan bercermin pada praktek serupa yang diterapkan di berbagai negara. Sebagaimana diuraikan pada bagian sebelumnya, penilaian merger dan akusisi dapat dibedakan atas 3 jenis penilaian yaitu: (i) penilaian atas permohonan konsultasi, (ii) penilaian atas penyampaian notifikasi, dan (iii) penilaian sederhana. Dalam menindaklanjuti penyampaian notifikasi dan permohonan konsultasi sendiri pada dasarnya terdapat 3 tahapan yang meliputi: (i) tahapan klarifikasi dan penelitian dokumen, (ii) tahapan penilaian awal, dan (iii) tahapan penilaian menyeluruh jika dibutuhkan.

Setiap jenis dan tahapan dalam penilaian tersebut mencerminkan kegiatan-kegiatan yang membutuhkan pendanaan baik untuk sumber daya manusia yang terlibat maupun operasional kegiatan yang perlu dibiayai melalui APBN. Namun demikian, perlu juga dipertimbangkan hal lain seperti aturan batas waktu pelaksanan dalam tiap tahapan dan output yang mungkin dihasilkan. Sebagai contoh, penilaian awal dan penilaian menyeluruh merupakan satu kesatuan proses penilaian dengan keseluruhan jangka waktu pelaksanaan paling lama 90 hari kerja. Hal ini menyebabkan penilaian awal dan penilaian menyeluruh sulit dipisahkan menjadi jenis PNBP tersendiri sebagaimaan diterapkan di beberapa negara. Terlebih lagi output dari keseluruhan proses penilaian adalah hanya satu jenis yaitu Penetapan Notifikasi atau Penetapan Konsultasi.

Atas dasar pertimbangan tersebut maka usulan jenis PNBP dalam penilaian merger dan akusisi adalah sebagaimana disajikan pada Tabel 3. Nomor 1 pada tabel tersebut adalah jenis PNBP untuk penilaian sederhana, nomor 2 dan 3 adalah jenis PNBP untuk penilaian 
atas penyampaian notifikasi, serta nomor 4 dan 5 adalah jenis PNBP untuk penilaian atas permohonan konsultasi. Tahapan klarifikasi dan penilaian pada proses notifikasi dan konsultasi dapat dipisahkan menjadi jenis PNBP tersendiri karena memiliki batasan waktu yang jelas (6o hari untuk klarifikasi dan 90 hari untuk penilaian) serta dapat menghasilkan output yang jelas.

Tabel 3. Usulan Jenis PNBP Atas Penilaian Merger dan Akuisisi

\begin{tabular}{|c|c|c|c|c|}
\hline No & Jenis PNBP & $\begin{array}{l}\text { Waktu } \\
\text { Penyelesaian }\end{array}$ & Output Yang Dihasilkan & Kegiatan / Aktivitas \\
\hline 1 & $\begin{array}{l}\text { PNBP atas } \\
\text { Notifikasi Dengan } \\
\text { Penilaian Sederhana }\end{array}$ & $\begin{array}{l}\text { Paling lama } 14 \\
\text { hari kerja }\end{array}$ & $\begin{array}{l}\text { Penetapan Notifikasi atau } \\
\text { Surat Pemberitahuan } \\
\text { dilaksanakannya prosedur } \\
\text { notifikasi regular }\end{array}$ & $\begin{array}{l}\text { Meliputi analisis pasar } \\
\text { bersangkutan, pangsa } \\
\text { pasar, konsentrasi pasar, } \\
\text { integrasi vertikal dan } \\
\text { kemungkinan melakukan } \\
\text { bundling/tying-in }\end{array}$ \\
\hline 2 & $\begin{array}{l}\text { PNBP atas } \\
\text { Klarifikasi dan } \\
\text { Penelitian dokumen } \\
\text { notifikasi merger } \\
\text { dan akusisi }\end{array}$ & $\begin{array}{l}\text { Paling lama } 60 \\
\text { hari kerja }\end{array}$ & $\begin{array}{l}\text { Penetapan Tidak Wajib } \\
\text { Notifikasi atau keputusan } \\
\text { untuk dilanjutkan ke tahap } \\
\text { penelitian }\end{array}$ & $\begin{array}{l}\text { Meliputi klarifikasi dan } \\
\text { penelitian atas informasi } \\
\text { dan dokumen pendukung } \\
\text { yang disampaikan dan } \\
\text { proses meminta dokumen } \\
\text { lanjutan }\end{array}$ \\
\hline 3 & $\begin{array}{l}\text { PNBP atas } \\
\text { Penilaian Notifikasi } \\
\text { Merger dan } \\
\text { Akuisisi }\end{array}$ & $\begin{array}{l}\text { Paling lama } 90 \\
\text { hari kerja }\end{array}$ & $\begin{array}{l}\text { Penetapan Notifikasi yang } \\
\text { memuat pendapat KPPU } \\
\text { terkait merger dan akuisisi }\end{array}$ & $\begin{array}{l}\text { Meliputi seluruh kegiatan } \\
\text { penilaian mulai dari } \\
\text { penilaian awal, dan jika } \\
\text { dibutuhkan dilanjutkan ke } \\
\text { penilaian menyeluruh }\end{array}$ \\
\hline 4 & $\begin{array}{l}\text { PNBP atas } \\
\text { Klarifikasi dan } \\
\text { Penelitian dokumen } \\
\text { konsultasi merger } \\
\text { dan akusisi }\end{array}$ & $\begin{array}{l}\text { Paling lama } 60 \\
\text { hari kerja }\end{array}$ & $\begin{array}{l}\text { Penetapan Tidak Wajib } \\
\text { Notifikasi atau keputusan } \\
\text { untuk dilanjutkan ke tahap } \\
\text { penelitian }\end{array}$ & $\begin{array}{l}\text { Meliputi klarifikasi dan } \\
\text { penelitian atas informasi } \\
\text { dan dokumen pendukung } \\
\text { yang disampaikan dan } \\
\text { proses meminta dokumen } \\
\text { lanjutan }\end{array}$ \\
\hline 5 & $\begin{array}{l}\text { PNBP atas } \\
\text { Penilaian } \\
\text { Konsultasi Merger } \\
\text { dan Akuisisi }\end{array}$ & $\begin{array}{l}\text { Paling lama } 90 \\
\text { hari kerja }\end{array}$ & $\begin{array}{l}\text { Penetapan Konsultasi atau } \\
\text { Penetapan Notifikasi yang } \\
\text { memuat pendapat KPPU } \\
\text { terkait merger dan akuisisi }\end{array}$ & $\begin{array}{l}\text { Meliputi seluruh kegiatan } \\
\text { penilaian mulai dari } \\
\text { penilaian awal, dan jika } \\
\text { dibutuhkan dilanjutkan ke } \\
\text { penilaian menyeluruh }\end{array}$ \\
\hline
\end{tabular}

Sumber: hasil olahan penulis berdasarkan UU No. 5/1999, PP No. 57/2010, Perkom No. 13/2019, dan Pedoman Penilaian Merger dan Akuisisi

Langkah selanjutnya setelah diperoleh jenis PNBP adalah menentukan tarif atas jenis PNBP tersebut. UU No. 9/2018 memberi arahan bahwa PNBP terkait pelayanan merupakan bentuk service charged atau pemungutan kepada masyarakat yang mendapatkan pelayanan dari pemerintah. Dalam ketentuan tersebut ditekankan bahwa pungutan dimaksud bukan dalam rangka mendapatkan keuntungan namun untuk memperbaiki kualitas layanan itu sendiri. Selanjutnya dikemukakan pula bahwa penentuan tarif PNBP yang berasal dari pelayanan perlu mempertimbangkan: (i) dampak pengenaan tarif terhadap masyarakat, dunia usaha, dan sosial budaya, (ii) biaya penyelenggaraan layanan, (iii) aspek keadilan, dan/atau (iv) kebijakan pemerintah. Tarif atas jenis PNBP itu sendiri dapat berbentuk: (i) tarif spesifik atau tarif yang ditetapkan dengan nilai nominal uang, dan/atau (ii) tarif ad-velorem yang antara lain ditentukan berdasarkan persentase dan formula tertentu. 
Praktek pengenaan biaya penilaian merger dan akuisisi di beberapa negara pada umumnya mengenakan model tarif spesifik dengan nilai nominal biaya per jenis kegiatan. Pada negara yang menggunakan pendekatan ad-velorem adalah berdasarkan persentase nilai transaksi yang dilengkapi dengan koridor tarif sehingga besaran tarifnya tidak akan bisa terlalu tinggi. Pada contoh negara-negara yang telah diuraikan sebelumnya, rentang tarif ini cukup bervariasi antara beberapa puluh juta Rupiah sampai dengan beberapa miliar Rupiah untuk tiap proses notifikasi.

Penentuan tarif atas jenis PNBP penilaian merger dan akusisi di Indonesia diusulkan didasarkan atas perhitungan biaya yang timbul dari tiap jenis penyediaan layanan penilaian merger dan akuisisi. Penghitungan tarif ini tidak dibahas dalam tulisan ini karena membutuhkan data internal KPPU yang cukup detil mengenai biaya sumber daya manusia yang terlibat dan kebutuhan biaya operasional lainnya dalam tiap jenis PNBP yang diusulkan. Hasil perhitungan biaya tersebut dapat saja dikalikan faktor pengurang atau penambah (mark-up) yang dikaitkan dengan pertimbangan dampak terhadap dunia usaha dan kebijakan pemerintah.

\section{Kesimpulan dan Rekomendasi}

Berdasarkan uraian di atas dapat ditarik kesimpulan mengenai peluang pengenaan tarif PNBP atas penilaian merger dan akuisisi dan usulan jenis PNBP yang dapat diterapkan. Selanjutnya berdasarkan kesimpulan tersebut disusun rekomendasi yang berisi langkahlangkah untuk menindaklanjuti peluang yang ada guna memperkuat pendanaan negara bagi terwujudnya transformasi ekonomi.

\subsection{Kesimpulan}

Saat ini KPPU belum mengenakan biaya atas penilaian terkait penerimaan notifikasi dan permohonan konsultasi merger dan akuisisi. Padahal, di beberapa negara praktek tersebut sudah lazim diterapkan untuk membiayai aktivitasnya dan sebagai bentuk partisipasi pelaku usaha atas pelayanan yang diterimanya. Selain itu, berdasarkan tinjauan regulasi khususnya UU No. 9/2018, pengenaan biaya tersebut sangat dimungkinkan karena penilaian merger dan akuisisi merupakan wujud dari pelaksanaan amanat UU No. 5/1999 dan aturan turunannya yang wajib dilakukan oleh KPPU.

Penentuan jenis PNBP dapat dikembangkan berdasarkan rangkaian kegiatan, jangka waktu dan keluaran dari proses penilaian merger dan akuisisi sebagaimana termuat dalam peraturan perundang-undangan. Atas dasar tersebut maka jenis PNBP atas penilaian merger dan akuisisi diusulkan terdiri atas: (i) PNBP atas Notifikasi Dengan Penilaian Sederhana, (ii) PNBP atas Klarifikasi dan Penelitian dokumen notifikasi merger dan akusisi, (iii) PNBP atas Penilaian Notifikasi Merger dan Akuisisi, (iv) PNBP atas Klarifikasi dan Penelitian dokumen konsultasi merger dan akusisi, dan (v) PNBP atas Penilaian Konsultasi Merger dan Akuisisi.

Setelah jenis PNBP disepakati maka langkah selanjutnya adalah menentukan tarif atas tiap jenis PNBP tersebut. Pada prinsipnya tarif PNBP adalah untuk memperbaiki kualitas layanan dan bukan ditujukan untuk mendapatkan keuntungan. Selain itu, penentuan tarif tersebut harus mempertimbangkan beberapa hal seperti dampaknya terhadap dunia usaha dan kebijakan pemerintah. Sejalan dengan hal tersebut maka diusulkan penentuan tarif 
PNBP tersebut didasarkan atas biaya yang dibutuhkan dalam penilaian merger dan akuisisi dengan beberapa penyesuaian sesuai kebutuhan.

\subsection{Rekomendasi}

Dalam menentukan jenis PNBP dan tarif atas jenis PNBP tersebut, KPPU perlu melakukan pembahasan dengan menteri yang menyelenggarakan urusan pemerintahan di bidang keuangan negara. Sebelumnya KPPU perlu melakukan perhitungan atas biaya penilaian merger dan akuisisi yang akan digunakan sebagai dasar penetapan tarif atas jenis PNBP tersebut.

Selanjutnya, KPPU perlu menyampaikan usulan perubahan atas PP No. 68/2015 untuk mengakomodasi jenis dan tarif PNBP atas penilaian merger dan akuisisi yang telah disepakati bersama dan kemudian bersiap diri menjalani proses pembentukan / pengubahan peraturan perundangan yang melibatkan para pemangku kepentingan.

\section{Daftar Pustaka}

ACCC. (2021). About Merger. Australian Competition and Consumer Commission. Tersedia dari https://www.accc.gov.au/business/mergers/about-mergers_[Diakses 13 Februari 2021]

Bundeskartellamt. (2021). Merger Control. The Bundeskartellamt. Tersedia dari https://www.bundeskartellamt.de/EN/Mergercontrol/mergercontrol_node.html

[Diakses 14 Februari 2021]

CBC. (2021). Reviewing Merger. Competition Bureau Canada. Tersedia dari https://www.competitionbureau.gc.ca/eic/site/cb-bc.nsf/eng/h_00114.html

[Diakses 15 Februari 2021]

CCCS. (2021). Notify a Merger. The Competition Commission of Singapore. Tersedia dari https://www.cccs.gov.sg/approach-cccs/notifying-a-merger [Diakses 15 Februari 2021]

CCI. (2021). Frequently Asked Questions. Competition Commission of India. Tersedia dari https://wwr.cci.gov.in/node/2847\# [Diakses 13 Februari 2021]

FTC. (2021). Merger Review. Federal Trade Commission of the United States of America. Tersedia dari https://www.ftc.gov/enforcement/merger-review [Diakses 14 Februari 2021]

Gov.UK. (2021). Mergers: Detailed information. The websites of all UK government

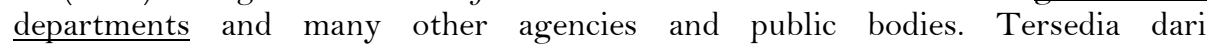
https://wwre.gov.uk/topic/competition/mergers [Diakses 14 Februari 2021]

KPPU-RI. (2020). Catatan Kinerja KPPU di Tahun 2020. Tersedia dari https://kppu.go.id/blog/2020/12/catatan-kinerja-kppu-di-tahun-2020/ [Diakses 12 Februari 2021]

KPPU-RI. (2019). Laporan Tahunan 2019: Capaian besar dimulai dari transformasi diri. Komisi Pengawas Persaingan Usaha Republik Indonesia. Jakarta. Tersedia dari kppu.go.id/wp-content/uploads/2020/06/Laporan-Tahunan-KPPU2019_ok.pdf [Diakses 12 Februari 2021]

KPPU-RI. (2018). Laporan Tahunan 2018: Semangat baru mengawal persaingan sehat. Komisi Pengawas Persaingan Usaha Republik Indonesia. Jakarta. Tersedia dari kppu.go.id/wp-content/uploads/2020/06/Laporan-Tahunan-2018.pdf

[Diakses 12 Februari 2021]

KPPU-RI. (2019). Peraturan Komisi Pengawas Persaingan Usaha Republik Indonesia Nomor 3 Tahun 2019 Tentang Penilaian Terhadap Penggabungan Atau Peleburan Badan Usaha, 
Atau Pengambilalihan Saham Perusahaan Yang Dapat Mengakibatkan Terjadinya Praktik Monopoli Dan/Atau Persaingan Usaha Tidak Sehat. Berita Negara RI Tahun 2019, No. 1130. Kementerian Hukum dan Hak Asasi Manusia. Jakarta.

KPPU-RI. (2020). Pedoman Penilaian Terhadap Penggabungan, Peleburan, Atau

Pengambilalihan. Komisi Pengawas Persaingan Usaha Republik Indonesia. Jakarta. Tersedia dari https://kppu.go.id/wp-content/uploads/2020/10/PedomanPenilaian-Terhadap-Penggabungan-Peleburan-Atau-Pengambialihan-FINAL.pdf

[Diakses 10 Februari 2021]

Mergerfilers.com. (2021). Merger Filing Guide: Thailand. Mergerfilers.com Global Legal

Guides.

Tersedia

dari

https://www.mergerfilers.com/guide.aspx?expertjuris=Thailand\#guidebook [Diakses 13 Februari 2021]

PCC. (2021). Merger Review Guidelines. The Philippine Competition Commission. Tersedia dari https://www.phcc.gov.ph/merger-review-guidelines-2/ [Diakses 14 Februari $2021]$

Pemerintah Republik Indonesia. 1999. Undang-Undang Nomor 5 Tahun 1999 tentang Larangan Praktek Monopoli dan Persaingan Usaha Tidak Sehat. Lembaran Negara RI Tahun 1999, No. 33. Sekretariat Negara. Jakarta.

Pemerintah Republik Indonesia. 2010. Peraturan Pemerintah Nomor 57 Tahun 2010 tentang Penggabungan Atau Peleburan Badan Usaha Dan Pengambilan Saham Perusahaan Yang Dapat Mengakibatkan Terjadinya Praktek Monopoli Dan Persaingan Usaha Tidak Sehat. Lembaran Negara RI Tahun 2010, Nomor 89. Sekretariat Negara. Jakarta.

Pemerintah Republik Indonesia. 2018. Undang-Undang Nomor 9 Tahun 2018 tentang Penerimaan Negara Bukan Pajak. Lembaran Negara RI Tahun 2018, No. 147. Sekretariat Negara. Jakarta.

Pemerintah Republik Indonesia. 2020. Peraturan Presiden Republik Indonesia Nomor 18 Tahun 2020 tentang Rencana Pembangunan Jangka Menengah Nasional Tahun 2020-2024. Lembaran Negara RI Tahun 2020, No. 10. Kementerian Hukum dan Hak Asasi Manusia. Jakarta.

Pemerintah Republik Indonesia. 2020. Undang-Undang Republik Indonesia Nomor 11 Tahun 2020 tentang Cipta Kerja. Lembaran Negara RI Tahun 2020, No. 245. Sekretariat Negara. Jakarta.

Pemerintah Republik Indonesia. 2021. Peraturan Pemerintah Nomor 44 Tahun 2021 tentang Pelaksanaan Larangan Praktek Monopoli Dan Persaingan Usaha Tidak Sehat. Lembaran Negara RI Tahun 2021, Nomor 54. Kementerian Hukum dan Hak Asasi Manusia. Jakarta.

Ragazzo, CEJ., dan Albuquerque, CL. (2012). From Post to Pre-Merger Notification: The Ultimate Outreach Challenge. CPI Antitrust Chronicle August 2012 (2), BePress.

Thomson Reuters. (2021). Merger control in The Netherlands: overview. Thomson Reuters

Practical Law. Tersedia dari https://uk.practicallaw.thomsonreuters.com/9-3846266? transitionType $=$ Default\&contextData $=($ sc. Default $) \&$ firstPage $=$ true $\#: \sim:$ text $=$ Filing\%20fee\&text=For\%20a\%20decision\%20in\%20the,decide\%20to\%20withdraw \%20their\%20notification [Diakses 13 Februari 2021] 
